\title{
Phylogenetic relationships and larval morphology of the recently described diving beetle genus Laccomimus (Coleoptera: Dytiscidae: Laccophilinae)
}

\author{
MARIANo C. MICHAT ${ }^{1}$ and MARIO TOLEDO ${ }^{2}$ \\ ${ }^{1}$ IBBEA, CONICET-UBA, Laboratory of Entomology, DBBE-FCEN, University of Buenos Aires, Argentina; \\ e-mail: marianoide@gmail.com \\ ${ }^{2}$ Museo di Storia Naturale, Università di Parma, via Farini 90, 43100 Parma, Italy; e-mail: toledo.pinguicula.mario3@gmail.com
}

Key words. Coleoptera, Dytiscidae, Laccophilini, Laccomimus, larva, morphometry, chaetotaxy, ground plan, phylogeny

\begin{abstract}
The larvae of the diving beetle genus Laccomimus Toledo \& Michat, 2015 (Laccophilinae) are studied for the first time, based on detailed descriptions and illustrations of all instars of L. distinctus Toledo \& Michat, 2015, with particular emphasis on morphometry and chaetotaxy. The phylogenetic relationships of this genus within the tribe Laccophilini are analyzed cladistically. Laccomimus is recovered as part of a clade that includes the genera Australphilus Watts, 1978, Neptosternus Sharp, 1882 and Laccophilus Leach, 1815 and is characterized by the presence of natatory setae on the tibia and tarsus, and within this clade it is a sister to the other genera. Third-instar larvae of Laccomimus and Africophilus Guignot, 1948 share the mediodistal insertion of the seta CO7 on the meso- and metacoxa, a short and spine-like seta TI6 on the metatibia, a ventrally sclerotized abdominal segment V and a short urogomphus. These characters are considered plesiomorphic and indicate a basal position of both genera within the Laccophilini. All instars of Laccomimus are characterized by the anterolateral lobes of the frontoclypeus clearly projecting beyond the anterior margin and the last abdominal segment strongly elongated. Diagnostic features of the first instar are: frontoclypeus unmodified posteriorly, lamellae clypeales thin and hair-like, pores ANe, MXb-d-f-i, LAb-c and seta TR3 absent, seta LA3 and an additional dorsal pore present on the prementum, abdominal tergites I-VII with anterior transverse carina, and ventral surface of the abdominal segment VI sclerotized.
\end{abstract}

\section{INTRODUCTION}

On a collecting trip in the Humid Chaco eco-region (Chaco Province, Argentina) seven years ago the senior author collected some unusual and particularly interesting diving beetle larvae in a pond with vegetation. After a more detailed examination under a microscope these larvae were thought to belong to the subfamily Laccophilinae. The resemblance with the (so far) only laccophiline genus known from Argentina (Laccophilus Leach, 1815) was, however, rather vague. The occurrence in the same habitat of adults of a small laccophiline species apparently not belonging to Laccophilus raised the question whether these unusual larvae actually belong to another genus, with Laccodytes Régimbart, 1895 being the most likely candidate. The adults collected in that habitat were recently studied in detail as part of an extensive revision of some Laccophilini genera (Toledo et al., 2010; Toledo \& Michat, 2015), which confirmed they do not belong to Laccophilus or Laccodytes but to a new genus, Laccomimus Toledo \& Michat, 2015.

The genus Laccomimus includes 12 species of small diving beetles (less than $3 \mathrm{~mm}$ in length) widespread in tropical America from Florida in the US to central Argentina, most commonly found in lentic or stagnant water rich in debris and vegetation (Toledo \& Michat, 2015). In particular, the adult specimens collected along with the larvae were described as a new species, L. distinctus Toledo \& Michat, 2015, and placed in an isolated phylogenetic position as the sister group of all the other species in this genus (Toledo \& Michat, 2015). All these findings make the remarkable larvae collected years ago a very interesting tar- get for study, as the immatures of Laccomimus have been unknown.

On the basis of adult characters, Laccomimus was found to be reliably placed within the tribe Laccophilini. After a cladistic analysis, it was hypothesized that it is a sister group of the Oriental genus Laccosternus Brancucci, 1983, both taxa forming a clade sister to Laccophilus (Toledo \& Michat, 2015). Larval morphology of the subfamily Laccophilinae is imperfectly known, with the larvae of several genera still unknown. Larval characters, however, have proven to be very useful in the study of the phylogenetic relationships within Dytiscidae. As different expressions of the same genotype, larval characters help to complement adult characters that are traditionally the primary basis for classification. In particular, larval chaetotaxy is a significant source of characters both for diagnosis of the genera and species and for the study of the phylogenetic relationships within the Laccophilinae (Alarie et al., 2000, 2002a; Michat, 2008). The development of a system of nomenclature for the primary sensilla (setae and pores) of first-instar larvae of this subfamily (Alarie et al., 2000) has revealed the taxonomic and phylogenetic value of this character set.

This paper is a contribution to a better understanding of the larval morphology of the Laccophilinae and has the following goals: (1) to describe and illustrate in detail the three larval instars of L. distinctus, with particular emphasis on an analysis of chaetotaxy of the cephalic capsule, head appendages, legs, last abdominal segment and urogomphi; (2) to compare the larval characters of Laccomimus with those of other laccophiline genera for which the 
larvae are described; and (3) to study the phylogenetic relationships of this genus within the tribe Laccophilini based on larval characters.

\section{MATERIAL AND METHODS}

\section{Preparation and description of the larvae}

Six specimens of instar I, five of instar II and seven of instar III were used for the descriptions. Larvae were collected in association with adults at the following locality: Argentina, Chaco Province, El Cachapé refuge, 4.xii.2008, small semi-permanent pond about $15 \mathrm{~m}$ long, $5 \mathrm{~m}$ wide and $70 \mathrm{~cm}$ in depth, with vegetation growing around the margins (see Figs 131 and 132 in Toledo \& Michat, 2015). It is most likely these larvae belong to L. distinctus as only adults of this species of Laccomimus were collected at this site.

Larvae were cleared in lactic acid, dissected and mounted on glass slides in polyvinyl-lacto-glycerol. Microscopic examination at magnifications of up to $1,000 \times$ and drawings were made using an Olympus CX31 compound microscope equipped with a camera lucida. Drawings were scanned and digitally inked using a Genius PenSketch tablet. Voucher specimens are deposited in the collection of M.C. Michat (Laboratory of Entomology, Buenos Aires University, Argentina).

The methods and terms used in the present paper follow those employed in previous papers dealing with the larval morphology and chaetotaxy of members of Laccophilinae. The reader is referred to Alarie et al. (2000, 2002a) and Michat (2008) for a complete list and additional explanations of the terms used in the present study.

\section{Chaetotaxic analysis}

Primary (present in instar I) and secondary (added throughout the ontogenetic development) setae and pores on the cephalic capsule, head appendages, legs, last abdominal segment and urogomphus were recorded. Sensilla were coded using two capital letters, in most cases corresponding to the first two letters of the name of the structure on which they are located, and a number (setae) or a lower case letter (pores). The following abbreviations were used: $\mathrm{AB}$ - abdominal segment VIII; AN - antenna; CO coxa; FE - femur; FR - frontoclypeus; LA - labium; MN - mandible; MX - maxilla; PA - parietal; PT - pretarsus; TA - tarsus; TI - tibia; TR - trochanter; UR - urogomphus. Setae and pores present in first-instar larvae were labelled using the ground plan of chaetotaxy of the subfamily Laccophilinae (Alarie et al., 2000, 2002a). Homologies were determined by using the criterion of similarity of position (Wiley, 1981). Setae located on the apices of the maxillary and labial palpi were extremely difficult to distinguish due to their position and small size, and, therefore, they are not well represented in the drawings.

\section{Phylogenetic analysis}

The phylogenetic relationships of the genus Laccomimus within the tribe Laccophilini were analyzed cladistically using the program TNT (Goloboff et al., 2008) and the character set provided by the larval morphology and chaetotaxy. The taxon sampling included all the Laccophilini genera for which larvae are known. Larvae of the genera Japanolaccophilus Satô, 1972, Laccodytes, Laccoporus J. Balfour-Browne, 1939, Laccosternus, Napodytes Steiner, 1981, Philaccolilus Guignot, 1937 and Philaccolus Guignot, 1937 are unknown. The genus Agabetes Crotch, 1873 (Agabetini) was included as an outgroup because it is considered a sister group of the Laccophilini (Miller, 2001). Data for most species [Agabetes acuductus (Harris, 1828), Laccomimus distinctus, Laccophilus hyalinus (De Geer, 1774), L. maculosus Say, 1823, L. minutus (Linnaeus, 1758), L. obliquatus Régimbart,
1889, L. paraguensis Régimbart, 1903, Neptosternus meridianus Omer-Cooper, 1970] were obtained directly from specimens and data for the remaining species (Africophilus montalentii Sanfilippo \& Franciscolo, 1988, Australphilus montanus Watts, 1978, A. saltus Watts, 1978, Neptosternus hydaticoides (Régimbart, 1877) from the literature (Alarie et al., 2000). Particular emphasis was placed on including characters of the third instar because this is the only instar known for all species. The lack of information on the first instar of several species, which results in many question marks in the matrix, prevented the inclusion of most characters from this semaphoront. All characters were treated as unordered and equally weighted. Multistate characters were treated as nonadditive. An exact solution algorithm (implicit enumeration) was implemented to find the most parsimonious trees. Bremer support values were calculated using the commands "hold 20000", "sub n" and "bsupport", where "n" is the number of extra steps allowed. The process was repeated increasing the length of the suboptimal cladograms by one step, until all Bremer values were obtained (Kitching et al., 1998). Bootstrap values were calculated using the following parameters: "standard (sample with replacement)"; 2,000 replicates.

\section{RESULTS}

\section{Description of the larvae of Laccomimus distinctus Toledo \& Michat, 2015}

Diagnosis. Occipital suture absent (Figs 1, 2, 17, 26); egg bursters basal (Figs 1, 2); spinulose epipharyngeal band well developed (Figs 1, 2, 17, 26); antenna short, robust (Figs 4, 5, 16, 26); A3 without ventroapical spinula (Fig. 5); GA small, subcylindrical (Figs 7, 26); abdominal segments VI-VIII completely sclerotized (Figs 1, 16); urogomphus composed of two urogomphomeres (Figs 1, 15, 25, 29); FR with two (instar I, Fig. 2), nine (instar II, Fig. 17) or 12 (instar III, Fig. 26) lamellae clypeales; setae MX5, MX6, MX9 (Figs 7-8), LA10, LA12 (Figs 9, 10, 20) and TR3 (Figs 11, 21, 27) absent; pores PAc (Figs 2, 17, 26), ANe, ANh (Figs 4, 5), MXb, MXd, MXf, MXi (Figs 7, 8), LAb and LAc (Figs 9, 10, 20) absent; prementum with one additional pore on dorsal surface (Fig. 9) and one secondary pore on ventral surface (Fig. 20); setae FE5, TI6 and TI7 short, spine-like (Figs 12, 22, 28); seta UR7 very long, inserted terminally on U1 (Figs 15, 25, 29); natatory setae on TI and TA scarce (Figs 22, 28); pore URc inserted terminally on U1 (Figs 15, 25); U without secondary setae (Figs 25, 29).

Instar I (Figs 1-15). Colour. Larva entirely brown except head appendages and legs, which are light brown, and the testaceous membranous parts.

Body (Fig. 1). Subcylindrical, narrowing towards abdominal apex. Measurements and ratios that characterize the body shape are shown in Table 1.

Head. Cephalic capsule (Figs 2-3). Subovate, somewhat longer than broad; surface covered with reticulated microsculpture; maximum width at level of stemmata; without neck constriction; occipital suture absent; ecdysial line well marked, coronal line moderately long; occipital foramen broadly emarginate ventrally; posterior tentorial pits visible ventrally; FR subtriangular, with two blunt egg bursters at base, anterior margin rounded medially, anterolateral lobes rounded, somewhat projecting beyond an- 


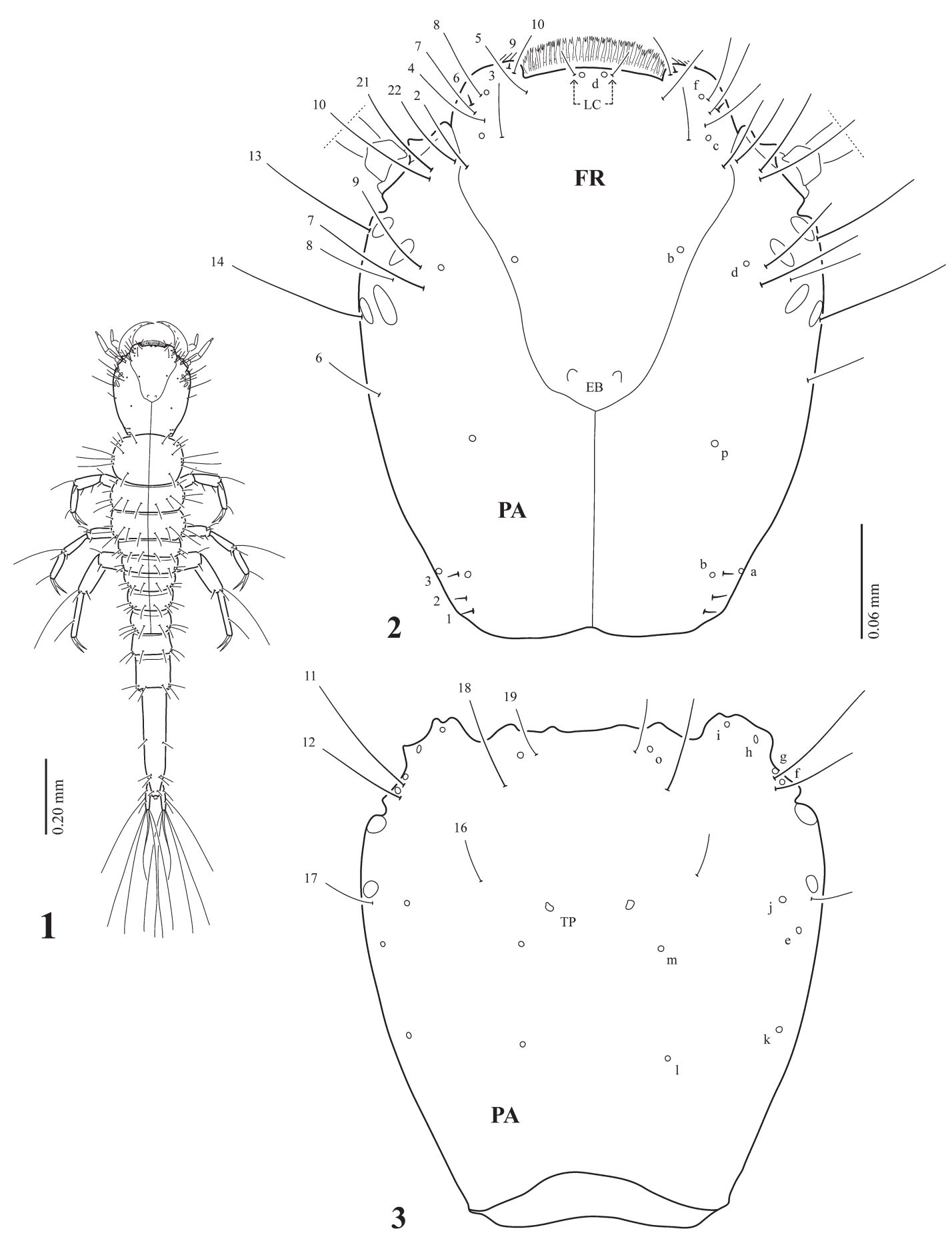

Figs 1-3. Laccomimus distinctus, first-instar larva. 1 - habitus, dorsal aspect; 2 - cephalic capsule, dorsal aspect; 3 - cephalic capsule, ventral aspect. Numbers and lowercase letters indicate primary setae and pores, respectively. EB - egg bursters; FR - frontoclypeus; LC - lamellae clypeales; PA - parietal; TP - tentorial pits.

terior margin, bearing slender spinulae on anterointernal angle; spinulose epipharyngeal band ("area o banda spinulosa del palato" of De Marzo, 1979) well developed, visible in dorsal view anterior to the lamellae clypeales; six lateral stemmata arranged in two curved vertical rows on each side. Antenna (Figs 4, 5). Short, robust, much shorter than HW, composed of four antennomeres; A1 the shortest, A4 slightly longer than A1, A2 and A3 the longest, subequal, A3 without ventroapical spinula; A3' (antennal sensorium) elongate. Mandible (Fig. 6). Prominent, broad basally, distal half projected inwards, apex sharp, with small denticles half way along the ventrointernal margin; mandibular channel present. Maxilla (Figs 7, 8). Cardo small, subovate; stipes short, robust, not sclerotized dorsally; GA small, subcylindrical; PPF short, palpomere-like; MP short, composed of three palpomeres, MP1 the shortest, MP2 and MP3 the longest, subequal. Labium (Figs 9, 10). Prementum well developed, subrectangular, broader than long, not sclerotized dorsally; LP short, composed of two palpomeres, LP2 longer than LP1. 
TABLE 1. Measurements of structures and their ratios for the three larval instars of Laccomimus distinctus.

\begin{tabular}{|c|c|c|c|}
\hline Measure & Instar I $(n=3)$ & Instar II $(n=4)$ & Instar III $(n=3)$ \\
\hline TL (mm) & $1.20-1.25$ & $2.20-2.80$ & $3.30-3.95$ \\
\hline MW (mm) & $0.25-0.30$ & $0.45-0.50$ & $0.70-0.80$ \\
\hline $\mathrm{HL}(\mathrm{mm})$ & $0.29-0.32$ & $0.42-0.43$ & $0.53-0.54$ \\
\hline $\mathrm{HW}(\mathrm{mm})$ & $0.26-0.27$ & $0.35-0.37$ & $0.47-0.48$ \\
\hline FRL (mm) & $0.18-0.19$ & 0.24 & $0.27-0.30$ \\
\hline $\mathrm{OCW}(\mathrm{mm})$ & $0.17-0.18$ & $0.14-0.17$ & $0.22-0.25$ \\
\hline $\mathrm{HL} / \mathrm{HW}$ & $1.13-1.19$ & $1.14-1.23$ & $1.13-1.17$ \\
\hline $\mathrm{HW} / \mathrm{OCW}$ & $1.50-1.53$ & $2.18-2.48$ & $1.92-2.18$ \\
\hline $\mathrm{COL} / \mathrm{HL}$ & $0.36-0.39$ & $0.43-0.45$ & $0.45-0.49$ \\
\hline FRL/HL & $0.61-0.64$ & $0.55-0.57$ & $0.51-0.55$ \\
\hline $\mathrm{A} / \mathrm{HW}$ & $0.54-0.56$ & $0.47-0.50$ & $0.43-0.46$ \\
\hline $\mathrm{A} 3 / \mathrm{A} 1$ & $4.00-4.29$ & $2.80-3.50$ & $2.14-2.50$ \\
\hline A3/A2 & $1.20-1.25$ & $1.08-1.27$ & $0.93-1.00$ \\
\hline $\mathrm{A} 4 / \mathrm{A} 3$ & $0.33-0.38$ & $0.36-0.38$ & $0.40-0.43$ \\
\hline A3'/A4 & $0.87-1.00$ & $0.80-1.00$ & $0.83-1.00$ \\
\hline MNL/MNW & $2.55-2.60$ & $2.57-2.85$ & $2.81-3.07$ \\
\hline $\mathrm{MNL} / \mathrm{HL}$ & $0.44-0.46$ & $0.42-0.44$ & $0.41-0.42$ \\
\hline $\mathrm{A} / \mathrm{MP}$ & $1.15-1.24$ & $1.17-1.32$ & $1.14-1.22$ \\
\hline GA/MP1 & $1.17-1.27$ & $0.40-0.75$ & 0.43 \\
\hline PPF/MP1 & $0.91-0.92$ & $0.60-1.00$ & 0.71 \\
\hline MP2/MP1 & $4.58-5.45$ & $2.80-3.50$ & $2.43-2.57$ \\
\hline MP2/MP3 & $1.09-1.20$ & $1.27-1.40$ & $1.55-1.64$ \\
\hline MP/LP & $2.80-3.03$ & $2.55-3.33$ & $2.77-3.00$ \\
\hline LP2/LP1 & $3.00-3.50$ & $2.00-2.67$ & $2.00-2.25$ \\
\hline $\mathrm{L} 3(\mathrm{~mm})$ & $0.70-0.75$ & $0.96-0.99$ & $1.24-1.30$ \\
\hline $\mathrm{L} 3 / \mathrm{L} 1$ & $1.23-1.26$ & $1.25-1.28$ & $1.28-1.32$ \\
\hline L3/L2 & $1.16-1.18$ & $1.16-1.21$ & $1.19-1.22$ \\
\hline $\mathrm{L} 3 / \mathrm{HW}$ & $2.70-2.79$ & $2.66-2.78$ & $2.60-2.74$ \\
\hline $\mathrm{L} 3(\mathrm{CO} / \mathrm{FE})$ & $0.91-0.92$ & $0.88-0.96$ & $0.94-0.97$ \\
\hline L3 (TI/FE) & $0.63-0.65$ & $0.60-0.64$ & $0.56-0.60$ \\
\hline L3 (TA/FE) & $0.91-0.92$ & $0.80-0.85$ & $0.69-0.73$ \\
\hline L3 (CL/TA) & $0.36-0.40$ & $0.28-0.39$ & $0.35-0.37$ \\
\hline $\operatorname{LAS}(\mathrm{mm})$ & $0.30-0.34$ & $0.45-0.49$ & $0.61-0.65$ \\
\hline LAS/HW & $1.15-1.26$ & $1.26-1.34$ & $1.29-1.38$ \\
\hline $\mathrm{U}(\mathrm{mm})$ & 0.35 & $0.39-0.44$ & $0.14-0.16$ \\
\hline U/LAS & $1.04-1.18$ & $0.86-0.90$ & $0.23-0.25$ \\
\hline U/HW & $1.31-1.37$ & 1.08 & $0.30-0.34$ \\
\hline $\mathrm{U} 1 / \mathrm{U} 2$ & 0.48 & $0.42-0.50$ & $1.21-1.64$ \\
\hline
\end{tabular}

Thorax. Terga convex, pronotum somewhat shorter than meso- and metanotum combined, meso- and metanotum subequal, wider than pronotum; protergite subrectangular, margins rounded, more developed than those of meso- and metatergite; meso- and metatergite transverse, with anterior transverse carina; all tergites covered with minute spinulae, with sagittal line well visible; sterna membranous; spiracles absent. Legs (Figs 11, 12). Moderately short, composed of six segments, L1 the shortest, L3 the longest; $\mathrm{CO}$ robust, elongate, TR divided into two parts by an annulus, FE, TI and TA slender, subcylindrical, PT with two long, slender, slightly curved claws, posterior claw shorter than anterior one on L1 and L2, claws subequal in length on L3; surface spinulae present on anterior surface of CO; rows of well-developed spinulae present on ventral margins of TI, TA and metaFE.

Abdomen. Eight-segmented; segments I-V sclerotized dorsally; segments I-III each with two ventral sclerites (those of segment I small) independent of dorsal sclerite; segments IV and $\mathrm{V}$ each with a single large independent ventral sclerite; segments VI-VIII completely sclerotized, ring-like; tergites $\mathrm{I}-\mathrm{V}$ narrow, transverse, rounded laterally, with sagittal line slightly visible; sclerites VI and VII more elongate; sclerites I-VII with anterior transverse
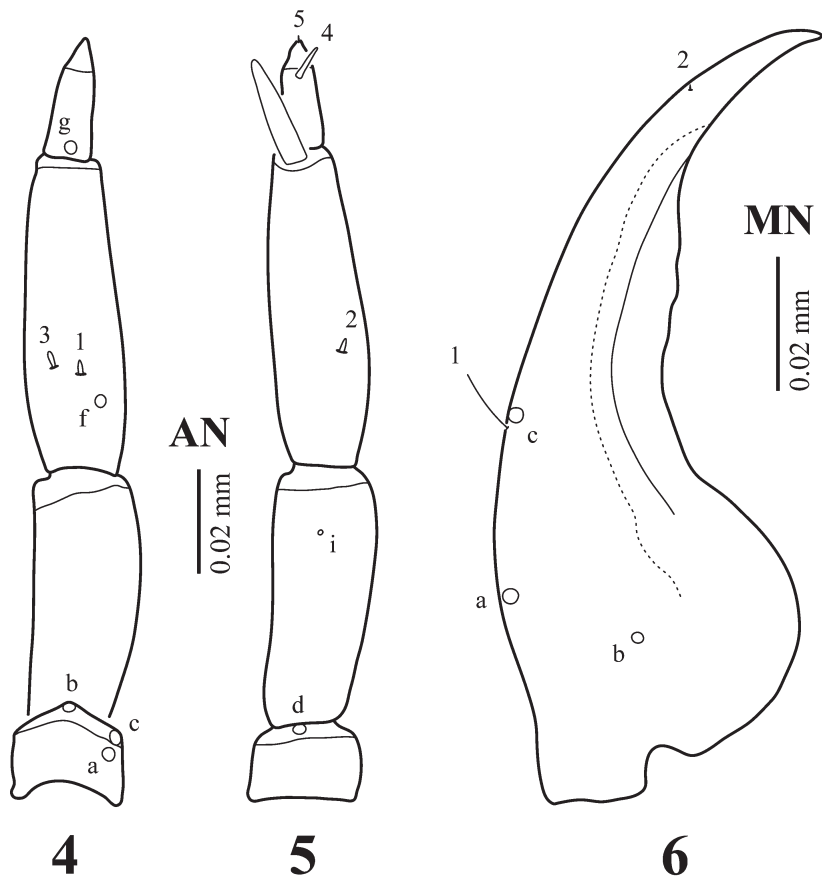

Figs 4-6. Laccomimus distinctus, first-instar larva. 4 - right antenna, dorsal aspect; 5 - left antenna, ventral aspect; 6 - left mandible, dorsal aspect. Numbers and lowercase letters indicate primary setae and pores, respectively. AN - antenna; $\mathrm{MN}$ - mandible.

carina, covered with minute spinulae; spiracles absent on segments I-VII; LAS (Figs 13, 14) very elongate, the longest; siphon relatively short, subconical. Urogomphus (Fig. 15). Moderately long, composed of two urogomphomeres; U1 shorter than LAS; U2 setiform, longer than U1.

Chaetotaxy (Figs 1-15). Similar to that of a generalized Laccophilinae larva (Alarie et al., 2000, 2002a; Michat, 2008) except for the following features: Pore PAc absent; pores ANe and ANh absent; setae MX5, MX6 and MX9 absent; pores MXb, MXd, MXf and MXi absent; setae LA10 and LA12 absent; pores LAb and LAc absent; prementum with one additional pore on dorsal surface (near seta LA8); seta CO7 inserted more proximally on L1; seta TR3 absent; seta FE4 inserted somewhat more proximally; seta FE5 short, spine-like; FE with one additional spine-like seta on anteroventral surface; seta TI4 on L2 and L3 long, hair-like, inserted distally, on L1 short, spine-like, inserted more proximally; seta TI6 short, spine-like; seta TA1 on L1 and L2 short, spine-like, inserted distally, on L3 long, hairlike, inserted more proximally; pores of the couples TAcTAd and TAe-TAf difficult to distinguish, there appears to be only one pore on each side; however, their presence in instars II and III indicates that they may be present also in instar I; setae AB2, AB9, AB10 and AB15 inserted more proximally; insertion of setae UR2 and UR3 contiguous; seta UR7 very long, inserted terminally on U1; although we were unable to distinguish seta UR1 on the urogomphus, we think it is present but obscured by the presence of basal spinulae (it is present in instars II and III).

Instar II (Figs 16-25). As instar I except for the following features: 

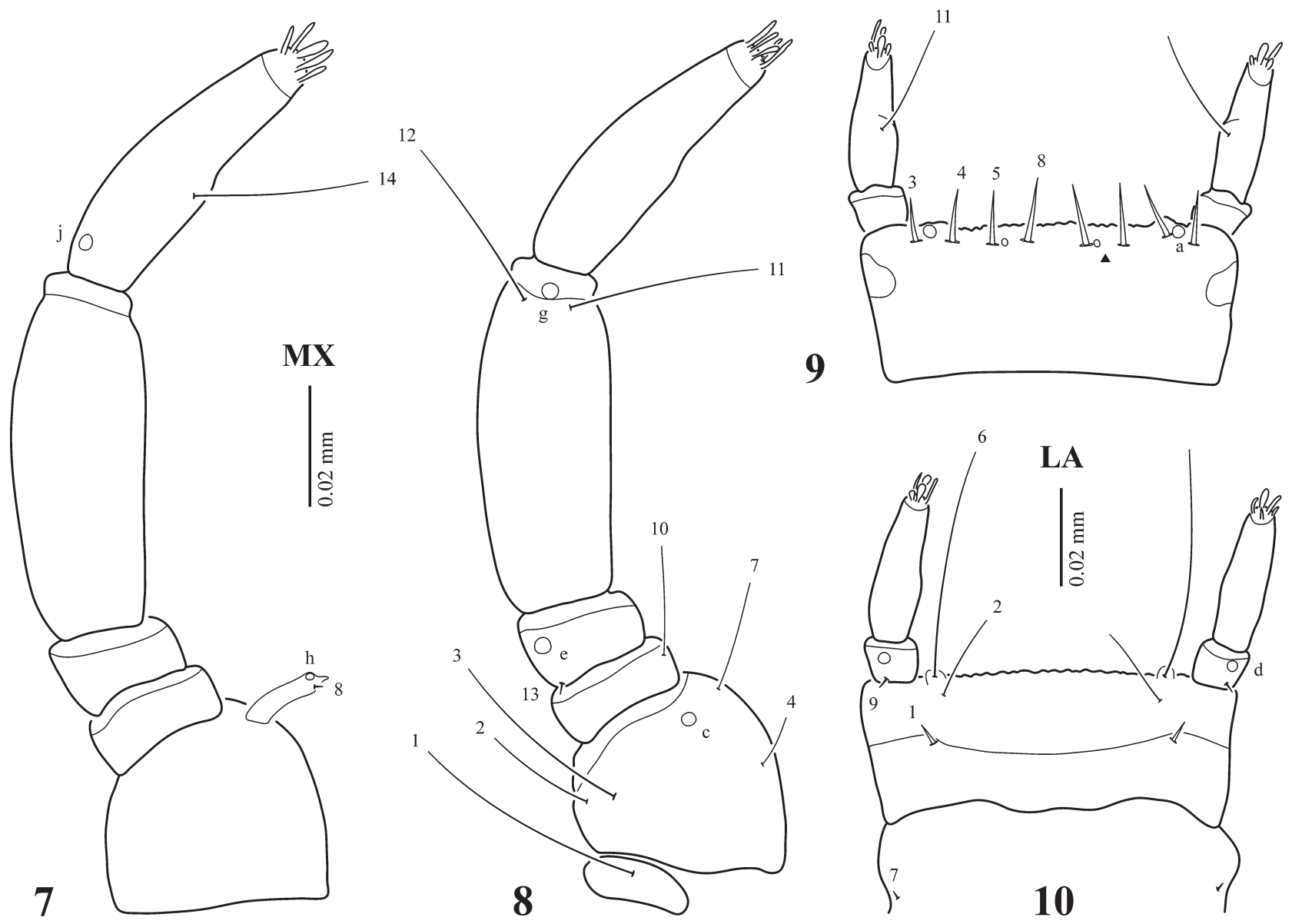

Figs 7-10. Laccomimus distinctus, first-instar larva. 7 - left maxilla, dorsal aspect; 8 - right maxilla, ventral aspect; 9 - labium, dorsal aspect; 10 - labium, ventral aspect. Numbers and lowercase letters indicate primary setae and pores, respectively. Additional pore indicated by a solid triangle. MX - maxilla; LA - labium.

Body (Fig. 16). Measurements and ratios are shown in Table 1.

Head. Cephalic capsule (Figs 17, 18). Neck constriction slightly marked; egg bursters absent. Maxilla. MP2 somewhat longer than MP3.

Thorax. Legs (Figs 21, 22). Spinulae on CO absent, spinulae on metaFE reduced.

Abdomen. Segment III with a single large ventral sclerite independent of the dorsal sclerite; tergite VI with sagittal line; sclerite VIII with anterior transverse carina.

Chaetotaxy (Figs 16-25). Cephalic capsule with numerous hair-like secondary setae, 3-4 spine-like setae on each lateral margin of PA, one spine-like seta on each side of dorsolateral surface of PA, and 2-4 spine-like setae on each side of ventrolateral surface of PA (Figs 17, 18); anterior margin of FR with nine short spine-like lamellae clypeales (Fig. 17); MN with one hair-like secondary seta on basoexternal margin (Fig. 19); prementum with one secondary pore on ventral surface (near seta LA1) (Fig. 20); thoracic tergites with secondary setae (Fig. 16), the marginal ones inserted on the apices of stout spinulae; secondary leg setation detailed in Table 2 and Figs 21 and 22; TR with one secondary pore on proximal portion; TI with one proximal natatory seta on posterodorsal margin; proTA without natatory setae; mesoTA with two natatory setae on posterodorsal margin; metaTA with four natatory setae on posterodorsal margin; abdominal sclerites with secondary setae (Fig. 16), the marginal ones inserted on the apices of stout spinulae; secondary setation on LAS detailed in Figs 23 and 24.

TABLE 2. Number and position of secondary setae on the legs of larvae of Laccomimus distinctus. Numbers separated by slash marks refer to pro-, meso- and metathoracic legs, respectively. $\mathrm{A}$ - anterior, D - dorsal, NS - natatory setae, $\mathrm{P}$ - posterior, $\mathrm{Pr}$ proximal, $\mathrm{V}$ - ventral, Total - total number of secondary setae on the structure, excluding primary (ancestral and additional) and natatory setae.

\begin{tabular}{lccc}
\hline Structure & Position & Instar II $(\mathrm{n}=4)$ & Instar III $(\mathrm{n}=3)$ \\
\hline \multirow{4}{*}{ Coxa } & $\mathrm{A}$ & $0-1 / 0-1 / 0-1$ & $1-2 / 1-3 / 3-4$ \\
& $\mathrm{PD}$ & $1-2 / 1-2 / 1-3$ & $3-5 / 4-5 / 3-5$ \\
& Total & $1-3 / 2-3 / 2-3$ & $5-6 / 6-8 / 6-9$ \\
\hline \multirow{2}{*}{ Trochanter } & Pr & $1 / 1 / 1$ & $1 / 1 / 1$ \\
& Total & $1 / 1 / 1$ & $1 / 1 / 1$ \\
\hline \multirow{2}{*}{ Femur } & AV & $0 / 0 / 0$ & $0 / 0 / 0-1$ \\
& Total & $0 / 0 / 0$ & $0 / 0 / 0-1$ \\
\hline \multirow{3}{*}{ Tibia } & AD & $1 / 1 / 1$ & $1-2 / 2-3 / 2-3$ \\
& PD (NS) & $1 / 1 / 1$ & $1 / 1 / 1$ \\
& Total & $1 / 1 / 1$ & $1-2 / 2-3 / 2-3$ \\
\hline \multirow{3}{*}{ Tarsus } & AD & $1 / 0 / 1$ & $1 / 0 / 1$ \\
& PD (NS) & $0 / 2 / 4$ & $0 / 2 / 4$ \\
& Total & $1 / 0 / 1$ & $1 / 0 / 1$ \\
\hline \multirow{4}{*}{} & & &
\end{tabular}




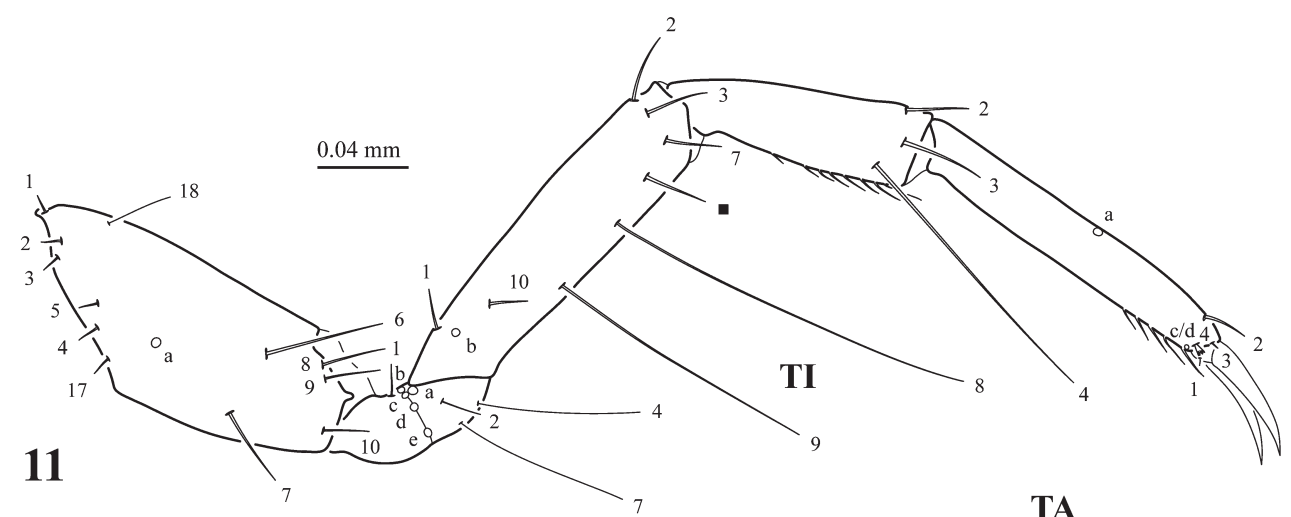

FE

TA

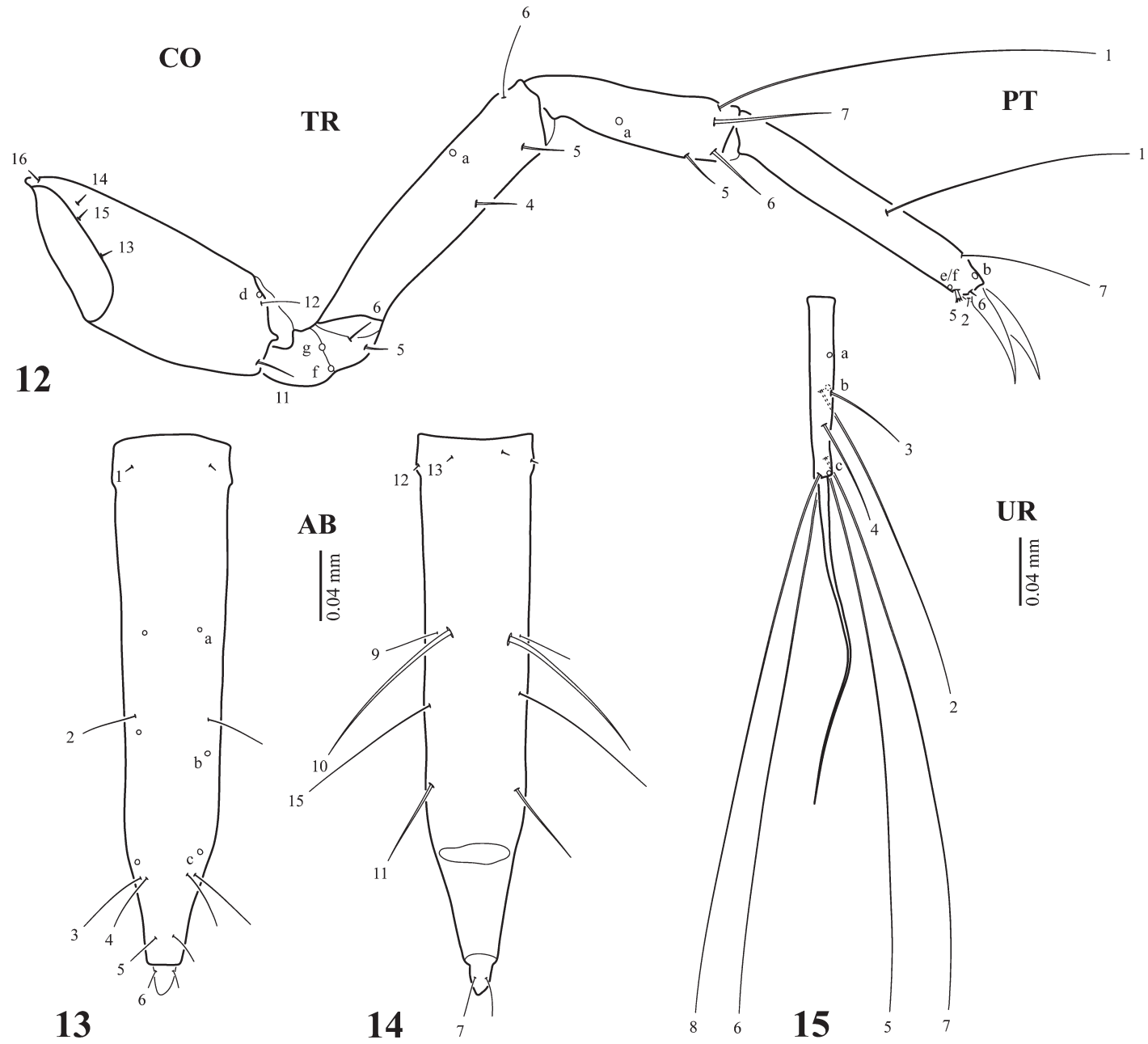

Figs 11-15. Laccomimus distinctus, first-instar larva. 11 - left metathoracic leg, anterior aspect; 12 - right metathoracic leg, posterior aspect; 13 - abdominal segment VIII, dorsal aspect; 14 - abdominal segment VIII, ventral aspect; 15 - right urogomphus, dorsal aspect. Numbers and lowercase letters indicate primary setae and pores, respectively. Additional seta indicated by a solid square. AB - abdominal segment VIII; CO - coxa; FE - femur; PT - pretarsus; TA - tarsus; TI - tibia; TR - trochanter; UR - urogomphus.

Instar III (Figs 26-29). As instar II except for the following features:

Body. Measurements and ratios are shown in Table 1.

Thorax. Non-functional spiracles present on mesothorax.

Abdomen. Segment II with a single large ventral sclerite independent of dorsal sclerite; non-functional spiracles present on segments I-VII, each on the apex of a small lobe. Urogomphus (Fig. 29). U2 shorter than U1.
Chaetotaxy (Figs 26-29). Secondary setation on cephalic capsule (Fig. 26), thoracic and abdominal sclerites more abundant; anterior margin of FR with 12 short spine-like lamellae clypeales (Fig. 26); PA with 7-10 spine-like setae on each lateral margin, 3-4 spine-like setae on each side of dorsal surface, and 9-10 spine-like setae on each side of ventral surface (Fig. 26); secondary leg setation detailed in Table 2 and Figs 27 and 28; secondary setation on LAS detailed in Fig. 29. 

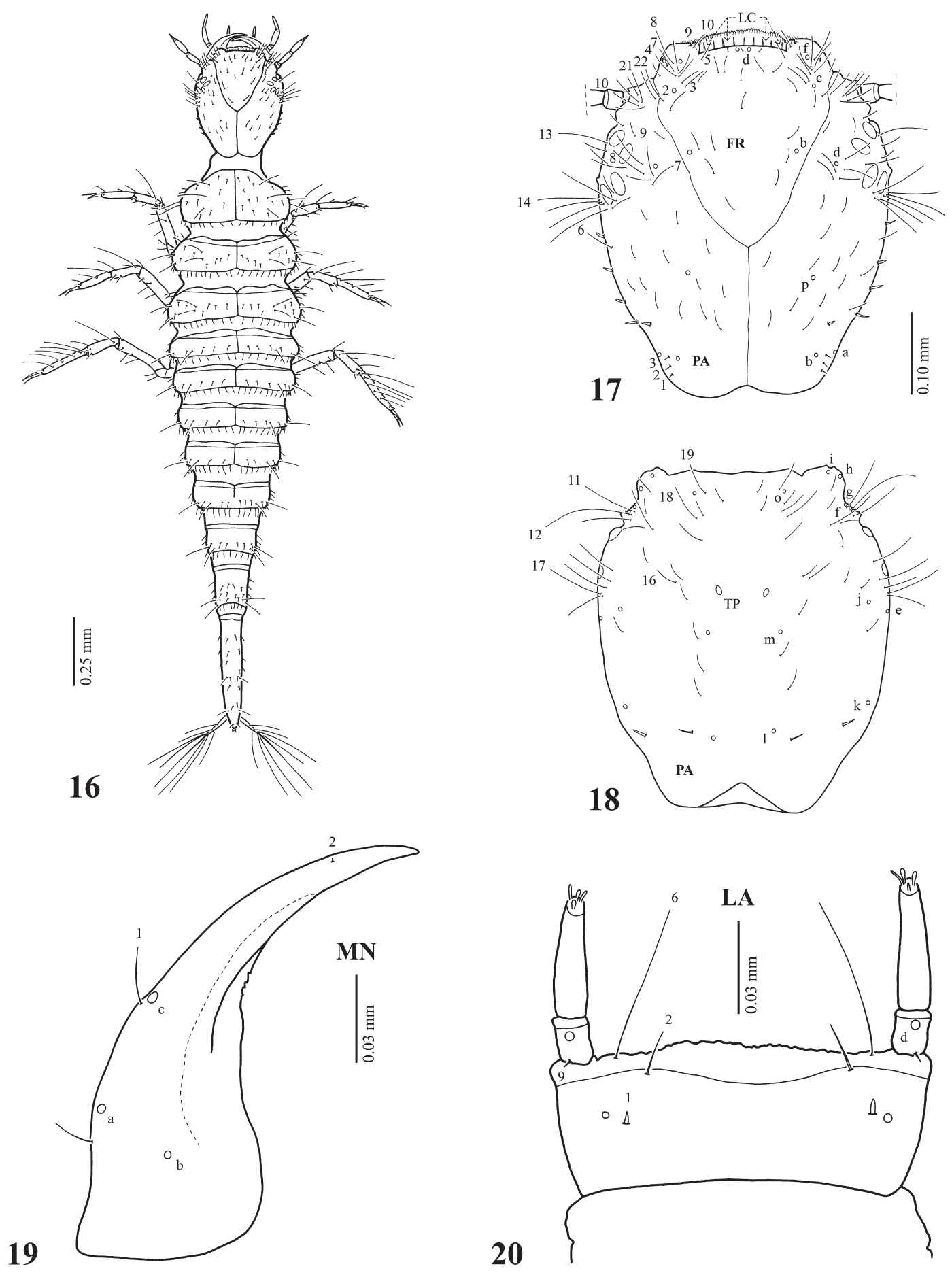

Figs 16-20. Laccomimus distinctus, second-instar larva. 16 - habitus, dorsal aspect; 17 - head, dorsal aspect; 18 - head, ventral aspect; 19 - left mandible, dorsal aspect; 20 - labium, ventral aspect. Numbers and lowercase letters indicate primary setae and pores, respectively. Secondary setae and pores not labelled. FR - frontoclypeus; LA - labium; LC - lamellae clypeales; MN - mandible; PA - parietal; TP - tentorial pits.

\section{Notes on the third-instar larva of Laccomimus bordoni Toledo \& Michat, 2015}

In a letter dated 1973 addressed to Paul J. Spangler (see Toledo \& Michat, 2015), Frank N. Young gives a description of the mature larva of $L$. bordoni (identified by association with adults) based on material collected in an open field on St. Croix, Virgin Islands. The letter is accompanied by a quite detailed drawing of the habitus (Figs 30,
31). In the last years of their lives, Young and Spangler no longer worked on taxa now included in Laccomimus, and therefore this description was never published. The comparison with $L$. distinctus reveals that the mature larvae of both species are very similar. Below we give an extract of Young's description of $L$. bordoni, including only the characters that differ from those of $L$. distinctus.

Colour: dorsal surface of head dark brown except markings around ocular area, bases of antennae, narrow area 


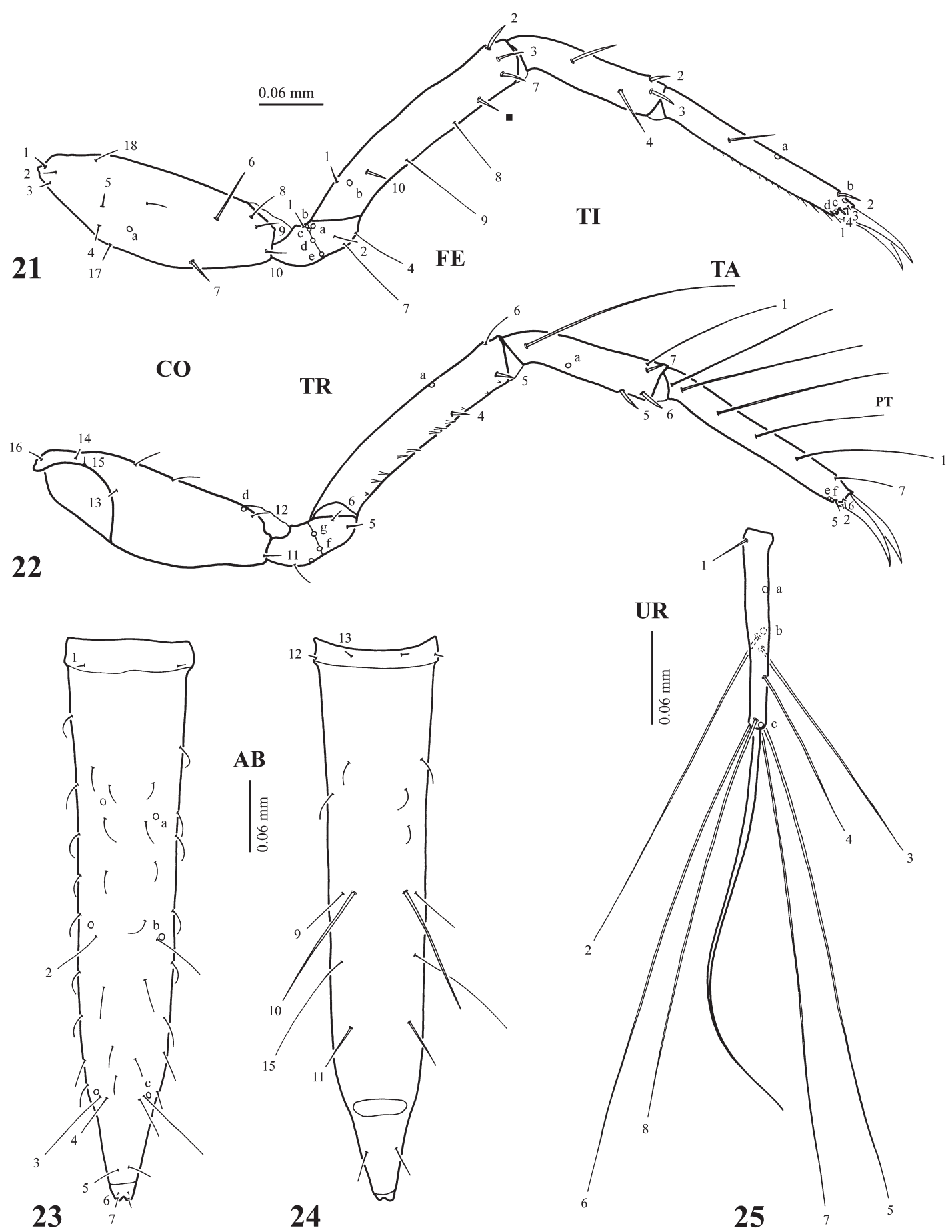

Figs 21-25. Laccomimus distinctus, second-instar larva. 21 - left metathoracic leg, anterior aspect; 22 - right metathoracic leg, posterior aspect; 23 - abdominal segment VIII, dorsal aspect; 24 - abdominal segment VIII, ventral aspect; 25 - right urogomphus, dorsal aspect. Numbers and lowercase letters indicate primary setae and pores, respectively. Additional seta indicated by a solid square. Secondary setae and pores not labelled. AB - abdominal segment VIII; CO - coxa; FE - femur; PT - pretarsus; TA - tarsus; TI - tibia; TR - trochanter; UR - urogomphus.

along frontoclypeal margins and extreme base of head that are testaceous; ventral surface of head dark brown except for the testaceous oral appendages; antenna and mandible testaceous; pronotal sclerite dark brown except for the testaceous anterolateral angles, longitudinal stripe between median ecdysial cleavage line and lateral margins and the fine ecdysial cleavage line; mesonotal sclerite dark brown except for the testaceous anterolateral margins; metanotal sclerite same as mesonotal sclerite except for a smaller and less obvious testaceous area; abdominal sclerites dark brown, apices of sclerites VI-VIII testaceous; ventral sclerites dark brown; legs testaceous; membranous areas creamy white.

Body: $\mathrm{TL}=3.60 \mathrm{~mm} ; \mathrm{MW}=0.85 \mathrm{~mm}$. 


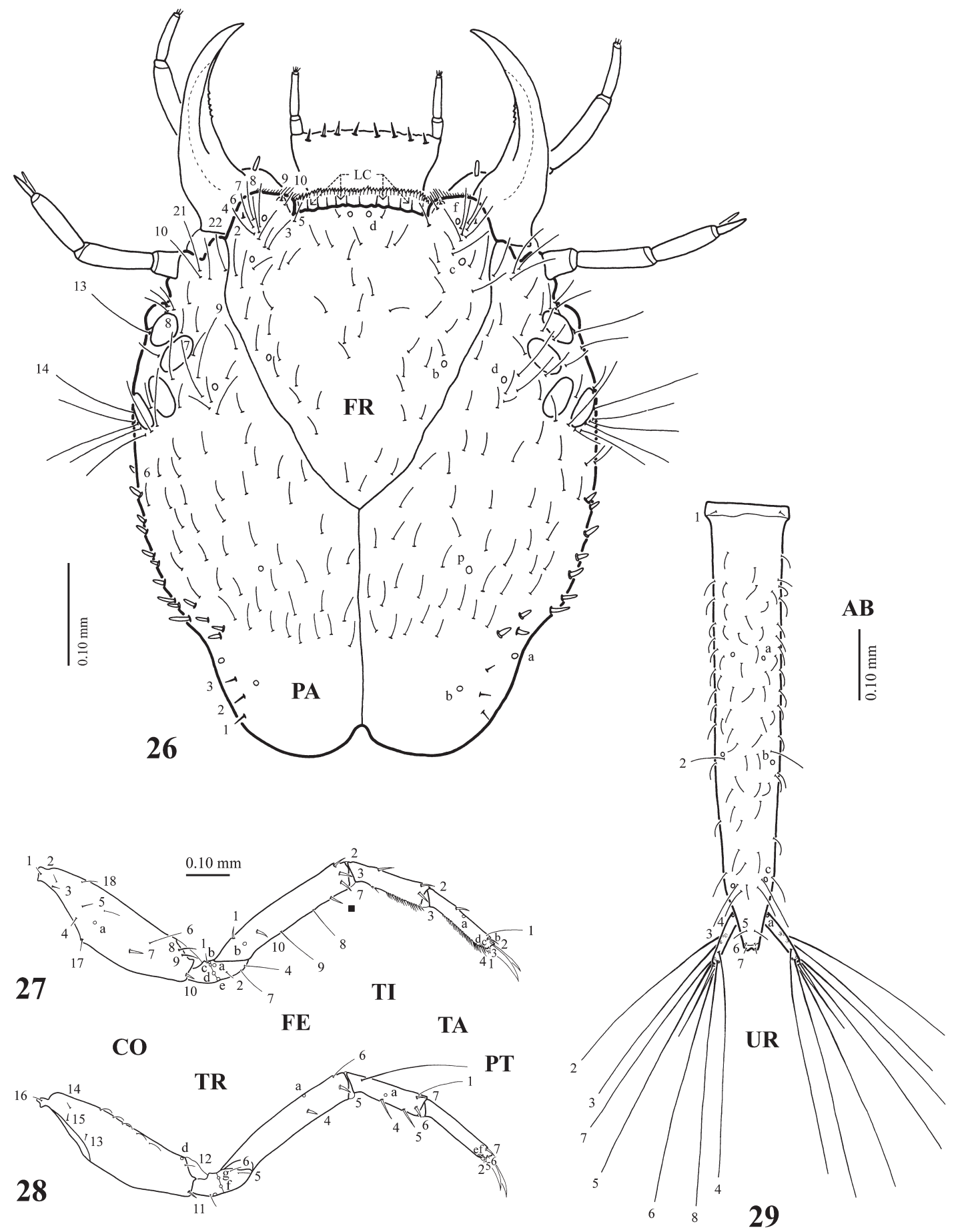

Figs 26-29. Laccomimus distinctus, third-instar larva. 26 - head, dorsal aspect; 27 - left prothoracic leg, anterior aspect; 28 - right prothoracic leg, posterior aspect; 29 - abdominal segment VIII and urogomphi, dorsal aspect. Numbers and lowercase letters indicate primary setae and pores, respectively. Additional seta indicated by a solid square. Secondary setae and pores not labelled. AB - abdominal segment VIII; CO - coxa; FE - femur; FR - frontoclypeus; LC - lamellae clypeales; PA - parietal; PT - pretarsus; TA - tarsus; TI - tibia; TR - trochanter; UR - urogomphus.

Abdomen: segment II with two large ventral sclerites independent of dorsal sclerite; terga of abdominal segments I-VI each with a lateral spiracle.

As we have not examined the larvae of L. bordoni, the morphological differences mentioned above should be approached with caution. The different degree of sclerotization on the ventral surface of abdominal segment II may be due to the different age of the larvae, and a more extensive sampling is needed to confirm this character. On the other hand, the presence of spiracles on the seventh abdominal segment is a common feature of Dytiscidae (including $L$. distinctus), therefore these structures may have been overlooked in L. bordoni. 

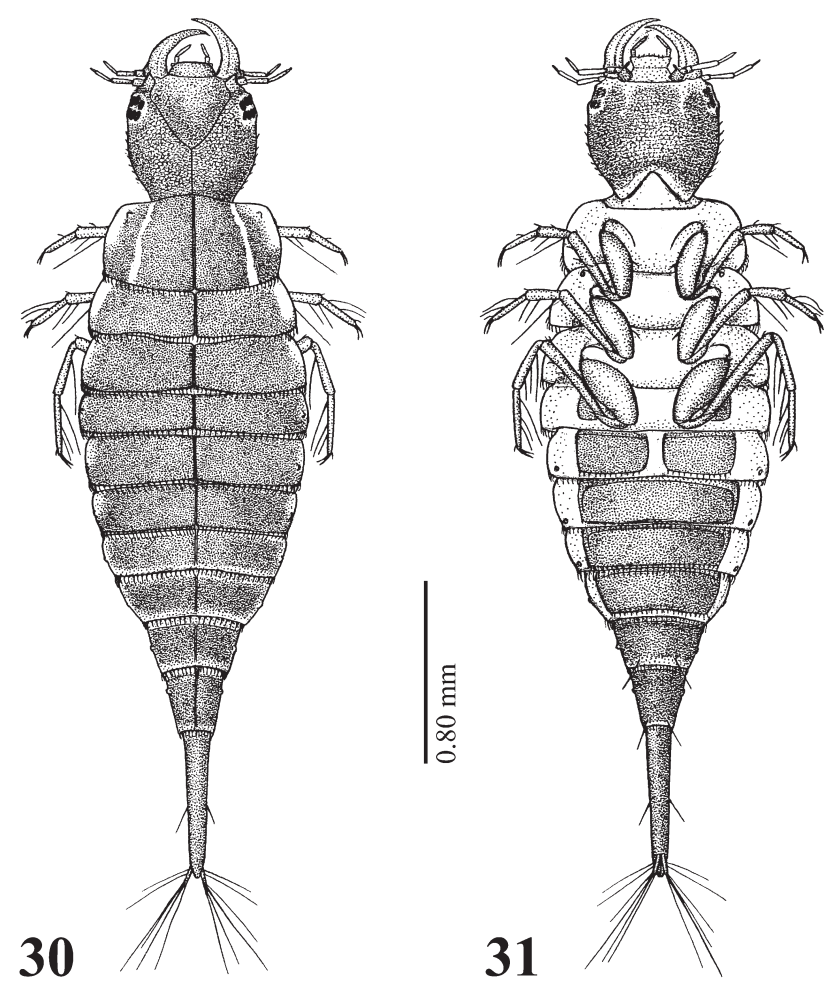

Figs 30-31. Laccomimus bordoni, third-instar larva. 30 - habitus, dorsal aspect; 31 - habitus, ventral aspect. Taken from Young (in litteris).

\section{Character analysis}

In total, 35 characters derived from the larval morphology and chaetotaxy were included, of which 34 were coded as binary and one as multistate (Appendix 1). The analysis of the data matrix (Appendix 2) with TNT resulted in three most parsimonious cladograms of 44 steps $(\mathrm{CI}=0.81$; $\mathrm{RI}=$ 0.88 ), which differed in the relative positions of the species of Laccophilus. The strict consensus was calculated (Fig. 32), in which Laccomimus is resolved as part of a large and weakly supported clade including also the genera Australphilus Watts, Neptosternus Sharp and Laccophilus. Within this group, Laccomimus is sister to the other genera, which form a well-supported clade. Character state changes are mapped on one of the most parsimonious trees (Fig. 33).

\section{DISCUSSION}

Larval morphology of members of the subfamily Laccophilinae is still imperfectly known. Several genera are unknown as larvae and only third-instar larvae are known for others. This hampers considerably any attempt to study the phylogeny within the subfamily based on larval characters. In particular, the lack of knowledge on the first instar (only three out of 13 genera known as larvae) prevented the inclusion of most characters from this semaphoront. Therefore, we elected to perform the cladistic analysis based mainly on characters of the third instar, avoiding the introduction in the data matrix of an excessively high number of question marks. Based on these premises, the phylogenetic analysis provided here should be considered as preliminary and subject to changes when more genera and additional larval stages are described.

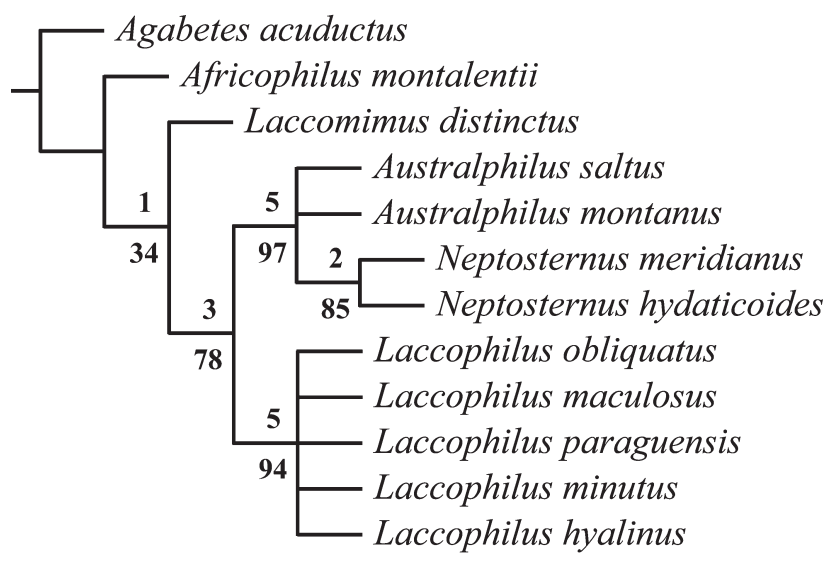

Fig. 32. Strict consensus cladogram obtained from the cladistic analysis based on 12 terminal taxa of Laccophilinae, with Bremer support values indicated above branches and Bootstrap support values indicated below branches.

Our phylogenetic analysis supports the placement of Laccomimus within the tribe Laccophilini. All the genera of this tribe are characterized by the presence of twosegmented urogomphi (character 32.1) and of secondary setae on the pro- and mesotibia (character 21.1) and on the dorsal surface of the protarsus (character 23.1), all character states absent in Agabetes (Agabetini) (Fig. 33). The phylogenetic signal of these characters, however, is weak as long as the presence of two-segmented urogomphi is a common feature of Dytiscidae as found in the Hydroporinae (Alarie \& Harper, 1990), most Agabinae (Alarie, 1995) and Copelatus Erichson, 1832 (Michat \& Torres, 2009), and secondary setae on the pro- and mesotibia and dorsal

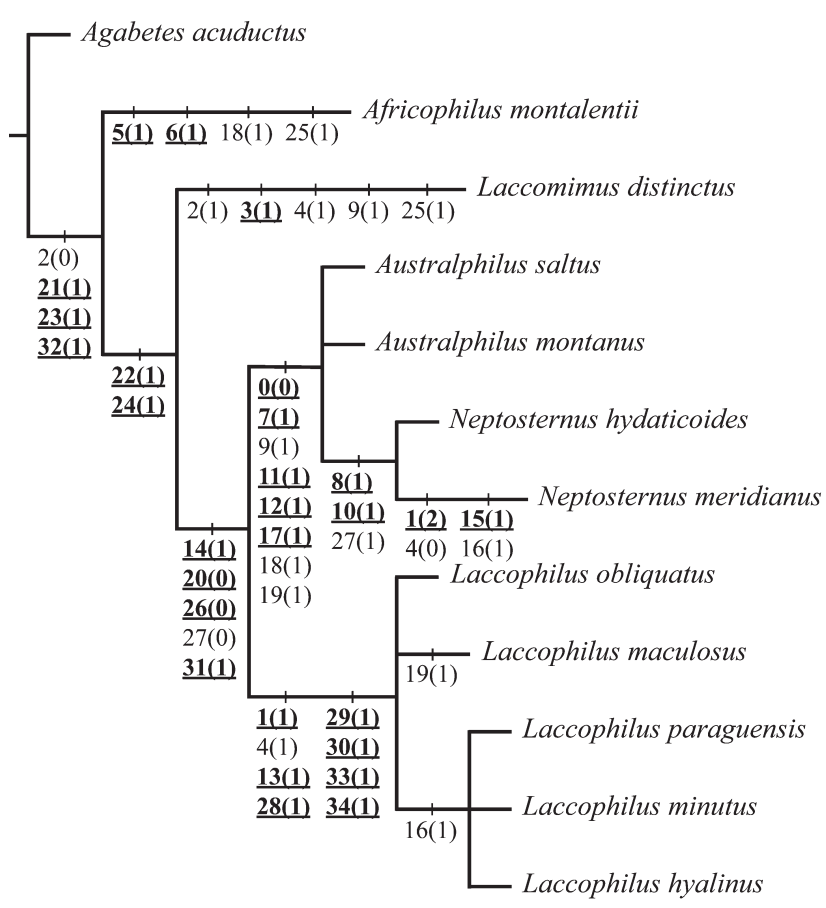

Fig. 33. One of the most parsimonious trees obtained from the cladistic analysis based on 12 terminal taxa of Laccophilinae, with character changes mapped for each clade. Numbers in bold underlined indicate unique character state transformations. 
surface of the protarsus occur in members of the Colymbetinae (Alarie et al., 2009), Dytiscinae (Michat \& Torres, 2005, 2006), Matinae (Alarie et al., 2001), Hydroporinae (Alarie \& Michat, 2007; Michat \& Torres, 2011), Agabinae (Michat \& Archangelsky, 2009) and Lancetinae (Alarie et al., 2002b).

Within the Laccophilini, Laccomimus is part of a large clade including all the genera known as larvae except $A f$ ricophilus Guignot, 1948 (Fig. 32), which is resolved as a sister to the rest of Laccophilini, in accordance with Alarie et al. (2000). The clade formed by all the genera except Africophilus is characterized by the presence of natatory setae on the posterodorsal surface of the tibia (character 22.1) and tarsus (character 24.1), which are absent in Africophilus and the outgroup (Agabetes) (Fig. 33). As with the previous characters, however, natatory setae on the posterodorsal surface of the tibia and tarsus are common features, present in several other subfamilies of Dytiscidae (see references above), and therefore cannot be used as strong evidence in support of the grouping mentioned above. The absence of natatory setae on the legs in Africophilus and Agabetes likely represents independent secondary losses associated with their peculiar habitats; Africophilus is hygropetric (Omer-Cooper, 1965), Agabetes inhabits the leafy substrate in woodland ponds (Spangler \& Gordon 1973) and some specimens were even taken from a wet leaf pack well above the water line (Larson et al. 2000).

It is interesting to note that the specimen recorded as "Laccodytes sp1" in Ribera et al. (2008) is actually a species of Laccomimus (Ignacio Ribera, pers. comm.). If this is taken into account, the results of our phylogenetic analysis are in very good agreement with the molecular results of Ribera et al. (2008). In this later paper Laccomimus is resolved as a sister to Africophilus and both a sister to a clade that includes all the other genera of Laccophilinae studied, among which are Australphilus, Neptosternus and Laccophilus. Our results recover Laccomimus and Africophilus as paraphyletic with respect to the other genera, although this is apparently due to the absence of natatory setae on the legs of both Africophilus and the outgroup Agabetes, which is most likely an independent loss. Laccomimus and Africophilus share a number of larval characters considered to be symplesiomorphies (see below), which means that the paraphyly of the two genera could change if more characters are added. This is also reflected in the low support values (Fig. 32).

The next branch of the tree separates the genus Laccomimus from the remaining genera (Australphilus, Neptosternus and Laccophilus) (Fig. 32). This relationship is relatively well supported by several characters. In fact, the clade Australphilus + Neptosternus + Laccophilus is characterized by four synapomorphies: (1) seta CO7 inserted proximally on the meso- and metacoxa (character 14.1); (2) seta TI6 long and hair-like on metatibia (character 20.0); (3) ventral surface of abdominal segment $\mathrm{V}$ membranous (character 26.0); (4) urogomphus elongate (character 31.1) (Fig. 33). The branching pattern Laccophi- lus (Australphilus, Neptosternus) is well supported in our tree (Fig. 32) and is in accordance with previous results of Alarie et al. (2000, 2002a), demonstrating that these three genera form a solid unit based on larval characters. Ribera et al. (2008), however, obtained a different branching pattern based on molecular data and a more comprehensive sampling of taxa. On the other hand, Laccomimus is supported by the anterolateral lobes of the frontoclypeus projecting beyond the anterior margin (character 2.1), which is shared with Agabetes but unique within the Laccophilini genera studied. This genus is also characterized by the apically rounded shape of the egg bursters (character 3.1), but this is a character of the first instar and therefore could not be evaluated for all the genera.

In a recent phylogenetic analysis of the Laccophilini based on adult characters (Toledo \& Michat, 2015), Laccomimus is a sister group of Laccosternus, and both taxa form a clade sister to Laccophilus. Unfortunately, the larvae of Laccosternus are unknown and therefore this hypothesis could not be tested in the present study. The relationship with Laccophilus, however, is rather distant in the larval tree and both genera differ in several larval characters (see Fig. 33). Laccomimus shares with Africophilus the mediodistal insertion of the seta $\mathrm{CO} 7$ on the meso- and metacoxa (character 14.0), a short and spine-like seta TI6 on the metatibia (character 20.1), the sclerotized ventral surface of abdominal segment V (character 26.1) and a short urogomphus (character 31.0). As similar states for these characters are present in the outgroup (Agabetes), they indicate a basal position of both genera within the Laccophilini. Interestingly, the frontoclypeus of the first instar is not modified in Laccomimus (character 1.0) (Fig. 2). A modified frontoclypeus, either truncate posteriorly as in Laccophilus or very narrow posteriorly as in Neptosternus, seems to be the rule among first-instar larvae of Laccophilini (De Marzo, 1976; Alarie et al., 2000; Michat, 2008). The fact that firstinstar larvae of Agabetes (Alarie et al., 2002a) also have an unmodified frontoclypeus is another argument in favour of a basal position of Laccomimus within the Laccophilini. It would be interesting to know if the frontoclypeus of Africophilus is modified, but unfortunately the first instar of this genus is unknown.

Including Laccomimus, the first instars of only three Laccophilini genera are described, which restricts the comparisons to a small fraction of the total number of genera. Nevertheless, it is interesting to discuss the most conspicuous differences exhibited by Laccomimus with respect to Laccophilus and Neptosternus (Alarie et al., 2000). It is well known that first-instar larvae of the Laccophilini have only two lamellae clypeales (De Marzo, 1976; Alarie et al., 2000; Michat, 2008), the lowest number recorded within the Dytiscidae. Laccomimus is not an exception, but unlike Laccophilus and Neptosternus, in which the lamellae are broad and spatulate, in this genus they are thin and hair like (Fig. 2) to the extent that they are difficult to distinguish from the other setae. Positional homology and presence of all other frontoclypeal setae commonly found in Dytiscidae, however, left little doubt that these two hair-like se- 
tae are in fact homologous to the lamellae clypeales. The pore MXd and the seta MX9 are absent on the maxilla of Laccomimus (Fig. 7), whereas they are present in Laccophilus and Neptosternus. Similarly, the labial pores LAb and LAc (Figs 9, 10) and the trochanteral seta TR3 (Fig. 11) are absent in Laccomimus and present in the other two genera. In contrast, the labial seta LA3 is present in Laccomimus, as well as an additional pore on the dorsal surface of the prementum (Fig. 9). These structures are absent in Laccophilus and Neptosternus. With respect to the abdomen, the tergites I-VII have an anterior transverse carina in Laccomimus, and the ventral surface of the segment VI is sclerotized, whereas segment VIII is considerably elongated as in the Cybistrini (Michat, 2006, 2010; Alarie et al., 2011) (Fig. 1). In Laccophilus and Neptosternus, the tergites I-VII lack an anterior transverse carina, segment VI is membranous ventrally and segment VIII is very short. Finally, the first instar of Laccomimus is highly characteristic in that the pores $\mathrm{ANe}, \mathrm{MXb}, \mathrm{MXf}$ and $\mathrm{MXi}$ are absent (Figs 5, 7, 8). These pores are present not only in Laccophilus and Neptosternus but also in the first-instar larvae of all dytiscid genera currently known (except $\mathrm{MXb}$, which is absent in Hydroporinae).

ACKNOWLEDGEMENTS. We are grateful to I. Ribera and an anonymous referee for their valuable comments on the manuscript. Thanks also to E. Boló Bolaño for giving us permission to collect aquatic Coleoptera in El Cachapé Wildlife Refuge. M.C. Michat was supported by project PIP 112-201101-01087 from CONICET.

\section{REFERENCES}

Alarie Y. 1995: Primary setae and pores on the legs, the last abdominal segment, and the urogomphi of larvae of Nearctic Colymbetinae (Coleoptera: Adephaga: Dytiscidae) with an analysis of their phylogenetic relationships. - Can. Entomol. 127: 913-943.

Alarie Y. \& Harper P.P. 1990: Primary setae and pores on the last abdominal segment and the urogomphi of larval Hydroporinae (Coleoptera: Adephaga: Dytiscidae), with notes on other dytiscid larvae. - Can. J. Zool. 68: 368-374.

Alarie Y. \& Michat M.C. 2007: Phylogenetic analysis of Hydroporinae (Coleoptera: Dytiscidae) based on larval morphology, with description of first instar of Laccornellus lugubris. - Ann. Entomol. Soc. Am. 100: 655-665.

Alarie Y., Michat M.C. \& Miller K.B. 2011: Notation of primary setae and pores on larvae of Dytiscinae (Coleoptera: Dytiscidae), with phylogenetic considerations. - Zootaxa 3087: 1-55.

Alarie Y., Nilsson A.N., Hendrich L., Watts C.H.S. \& Balke M. 2000: Larval morphology of four genera of Laccophilinae (Coleoptera: Adephaga: Dytiscidae) with an analysis of their phylogenetic relationships. - Insect Syst. Evol. 31: 121-164.

Alarie Y., WatTs C.H.S. \& Nilsson A.N. 2001: Larval morphology of the tribe Matini (Coleoptera: Dytiscidae: Colymbetinae): descriptions of Batrachomatus daemeli, Matus bicarinatus, and Allomatus nannup and phylogenetic relationships. - Can. Entomol. 133: 165-196.

Alarie Y., Spangler P.J. \& Steiner W.E., JR. 2002a: Larval morphology of Agabetes Crotch (Coleoptera: Adephaga: Dytiscidae): the hypothesis of sister-group relationship with the subfamily Laccophilinae revisited. - Coleopt. Bull. 56: 547-567.
Alarie Y., Archangelsky M., Nilsson A.N. \& Watts C.H.S. 2002b: Larval morphology of the genus Lancetes (Coleoptera: Adephaga: Dytiscidae): the hypothesis of sister-group relationship with the subfamily Dytiscinae revisited. - Can. Entomol. 134: 467-501.

De Marzo L. 1976: Studi sulle larve dei coleotteri ditiscidi. V. Note morfologiche sulle larve di tre specie del genere Laccophilus Leach. - Entomologica (Bari) 12: 107-129.

De Marzo L. 1979: Studi sulle larve dei coleotteri ditiscidi. X. Anatomia e funzionamento dell'apparato succhiante cibariofaringeo in alcune forme larvali delle subff. Dytiscinae, Colymbetinae, Laccophilinae e Hydroporinae. - Entomologica (Bari) 15: 5-72.

Goloboff P.A., Farris J. \& Nixon K. 2008: TNT, a free program for phylogenetic analysis. - Cladistics 24: 774-786.

Kitching I.J., Forey P.L., Humphries C.J. \& Williams D.M. 1998: Cladistics, 2nd ed. The Theory and Practice of Parsimony Analysis. Systematics Association Publications No. 11. Oxford University Press, New York, 228 pp.

Larson D.J., Alarie Y. \& Roughley R.E. 2000: Predaceous diving beetles (Coleoptera: Dytiscidae) of the Nearctic region, with emphasis on the fauna of Canada and Alaska. NRC Research Press, Ottawa, $982 \mathrm{pp}$.

Michat M.C. 2006: Descriptions of larvae of Megadytes (Coleoptera: Dytiscidae: Dytiscinae): The hypothesis of monophyletic origin revisited. - Eur. J. Entomol. 103: 831-842.

Мichat M.C. 2008: Description of the larvae of three species of Laccophilus Leach and comments on the phylogenetic relationships of the Laccophilinae (Coleoptera: Dytiscidae). Zootaxa 1922: 47-61.

Michat M.C. 2010: Descriptions of larvae of Megadytes (Coleoptera: Dytiscidae: Dytiscinae): The subgenera Trifurcitus and Megadytes s. str., ground plan of chaetotaxy of the genus and phylogenetic analysis. - Eur. J. Entomol. 107: 377-392.

Michat M.C. \& Archangelsky M. 2009: Phylogenetic relationships of Leuronectes Sharp (Coleoptera: Dytiscidae: Agabinae) based on larval morphology and chaetotaxy. - Insect Syst. Evol. 40: 209-228.

Michat M.C. \& ToRRes P.L.M. 2005: Larval morphology of Thermonectus succinctus (Aubé 1838) (Coleoptera: Dytiscidae: Dytiscinae), with biological notes and chaetotaxic analysis. Aquat. Insects 27: 281-292.

Michat M.C. \& Torres P.L.M. 2006: Hydaticus tuyuensis Trémouilles (Coleoptera: Dytiscidae): larval morphology and phylogenetic relationships within Dytiscinae. - Hydrobiologia 563: 479-492.

Michat M.C. \& Torres P.L.M. 2009: A preliminary study on the phylogenetic relationships of Copelatus Erichson (Coleoptera: Dytiscidae: Copelatinae) based on larval chaetotaxy and morphology. - Hydrobiologia 632: 309-327.

Michat M.C. \& Torres P.L.M. 2011: Phylogenetic relationships of the tribe Vatellini based on larval morphology, with description of Derovatellus lentus (Coleoptera: Dytiscidae: Hydroporinae). - Ann. Entomol. Soc. Am. 104: 863-877.

MiLLER K.B. 2001: On the phylogeny of the Dytiscidae (Insecta: Coleoptera) with emphasis on the morphology of the female reproductive system. - Insect Syst. Evol. 32: 45-92.

OMER-Cooper J. 1965: Coleoptera: Dytiscidae: A review of the Dytiscidae of Southern Africa being the results of the Lund University expedition 1950-1951, with which are incorporated all other records known to the author. In Hanström B., Brinck P. \& Rudebeck G. (eds): South Africa Animal Life, Vol 2. Statens Naturvetenskapliga Forskningsråd, Stockholm, pp. 59-214. 
Ribera I., Vogler A.P. \& Balke M. 2008: Phylogeny and diversification of diving beetles (Coleoptera: Dytiscidae). - Cladistics 24: 563-590.

Spangler P.J. \& GoRdon R.D. 1973: Descriptions of the larvae of some predacious water beetles (Coleoptera: Dytiscidae). Proc. Biol. Soc. Wash. 86: 261-278.

Toledo M. \& Michat M.C. 2015: Description of Laccomimus gen. n. and eleven new species from the Neotropical region (Coleoptera, Dytiscidae, Laccophilinae). — Zootaxa 3990: 301-354.

Toledo M., Spangler P.J. \& Balke M. 2010: Taxonomic revision of the Neotropical diving beetles genus Laccodytes Régimbart, 1895 (Coleoptera: Dytiscidae). - Zootaxa 2347: 37-58.

Wiley E.O. 1981: Phylogenetics. The Theory and Practice of Phylogenetic Systematics. John Wiley \& Sons, New York, 439 pp.

Received December 30, 2014; revised and accepted March 23, 2015 Prepublished online August 27, 2015

APPENDIX 1. Characters and states used in the phylogenetic analysis. Characters are those of third-instar larvae unless otherwise indicated.

(00) Spinulose epipharyngeal band: (0) absent; (1) present (Fig. 26).

(01) Frontoclypeus (instar I): (0) rounded or slightly pointed posteriorly (Fig. 2); (1) truncate posteriorly; (2) very narrow posteriorly.

(02) Anterolateral lobes of frontoclypeus: (0) well developed, not projecting beyond anterior margin; (1) well developed, projecting beyond anterior margin (Fig. 26).

(03) Shape of egg bursters (instar I): (0) spiniform; (1) rounded apically (Fig. 2).

(04) Pore PAc: (0) present; (1) absent (Fig. 26).

(05) Temporal spines: (0) present (Fig. 26); (1) absent.

(06) Antennomere 1: (0) longer than broad (Fig. 26); (1) broader than long.

(07) Pore ANf: (0) present (Fig. 4); (1) absent.

(08) Secondary setae on antennomere 1: (0) absent; (1) present

(09) Seta MX5: (0) present; (1) absent (Fig. 8).

(10) Secondary setae on maxillary palpomere 1: (0) absent; (1) present.

(11) Seta LA1: (0) seta-like (Fig. 10); (1) pore-like.

(12) Pronotum: (0) without neck constriction (Fig. 16); (1) with neck constriction.

(13) Row of comb-like spinulae (pecten) on posterodorsal surface of coxa: (0) absent (Fig. 28); (1) present.

(14) Seta CO7 on meso- and metacoxa: (0) inserted mediodistally (Fig. 21); (1) inserted proximally.

(15) Seta FE5 on mesofemur: (0) short, spine-like; (1) long, hairlike.
(16) Seta FE5 on metafemur: (0) short, spine-like (Fig. 22); (1) long, hair-like.

(17) Natatory posterodorsal setae on femur: (0) absent (Fig. 28); (1) present.

(18) Secondary anterodorsal setae on femur: (0) absent (Fig. 27); (1) present.

(19) Secondary posteroventral setae on femur: (0) absent (Fig. 28); (1) present

(20) Seta TI6 on metatibia: (0) long, hair-like; (1) short, spinelike (Fig. 22).

(21) Secondary setae on pro- and mesotibia: (0) absent; (1) present (Fig. 27).

(22) Natatory posterodorsal setae on tibia: (0) absent; (1) present (Fig. 28).

(23) Secondary dorsal setae on protarsus: (0) absent; (1) present (Fig. 27).

(24) Natatory posterodorsal setae on tarsus: (0) absent; (1) present (Fig. 22).

(25) Ventral surface of abdominal segment IV: (0) membranous; (1) sclerotized (Fig. 31)

(26) Ventral surface of abdominal segment V: (0) membranous; (1) sclerotized (Fig. 31).

(27) Ventral surface of abdominal segment VI: (0) membranous; (1) sclerotized (Fig. 31).

(28) Pore ABc: (0) present (Fig. 29); (1) absent.

(29) Siphon: (0) without a crescent shaped setal pattern (Fig. 29); (1) with a crescent shaped setal pattern.

(30) Dense cluster of secondary spine-like setae on basodorsal surface of siphon: (0) absent (Fig. 29); (1) present.

(31) Urogomphus: (0) short (Fig. 29); (1) elongate.

(32) Urogomphus: (0) composed of one urogomphomere; (1) composed of two urogomphomeres (Fig. 29).

(33) Urogomphomere 1: (0) subbasal suture absent (Fig. 29); (1) subbasal suture present.

(34) Secondary setae on urogomphus: (0) absent (Fig. 29); (1) present.

APPENDIX 2. Data matrix used in the cladistic analysis.

\begin{tabular}{|c|c|c|c|c|c|c|c|}
\hline Species & Chara & cter & & & & & \\
\hline & 00000 & 00000 & 11111 & 11111 & 22222 & 22222 & 33333 \\
\hline & 01234 & 56789 & 01234 & 56789 & 01234 & 56789 & 01234 \\
\hline Agabetes acuductus & 10100 & 00000 & 00000 & 00000 & 10000 & 01100 & 00000 \\
\hline Africophilus montalentii & $1 ? 0 ? ?$ & 11000 & 00000 & 00010 & 11010 & $111 ? 0$ & 00100 \\
\hline Australphilus montanus & $0 ? 0 ? ?$ & 00101 & 01101 & ??111 & $? 1111$ & $000 ? 0$ & 01100 \\
\hline Australphilus saltus & $0 ? 0$ ?? & 00101 & 01101 & ??111 & ?1111 & $000 ? 0$ & 01100 \\
\hline us distinctus & 10111 & 00001 & 00000 & 00000 & 11111 & 11100 & 00100 \\
\hline Laccophilus hyalinus & 11001 & $00 ? 00$ & 00011 & 01000 & 01111 & 00011 & 11111 \\
\hline Laccophilus maculosus & 11001 & 00000 & 00011 & 00001 & 01111 & 00011 & 11111 \\
\hline Laccophilus minutus & 11001 & $00 ? 00$ & 00011 & 01000 & 01111 & 00011 & 11111 \\
\hline Laccophilus obliquatus & 11001 & 00000 & 00011 & 00000 & 01111 & 00011 & 11111 \\
\hline Laccophilus paraguensis & 11001 & 00000 & 00011 & 01000 & 01111 & 00011 & 11111 \\
\hline Neptosternus hydaticoides & $S^{0} 0 ? 0 ? ?$ & 00111 & 11101 & ??111 & $? 1111$ & $001 ? 0$ & 01100 \\
\hline Neptosternus meridianus & 02000 & 00111 & 11101 & 11111 & 01111 & 00100 & 01100 \\
\hline
\end{tabular}

